\title{
Hexose Transport in Human Adipocytes: Factors Influencing the Response to Insulin and Kinetics of Methylglucose and Glucose Transport
}

\section{O. Pedersen and J. Gliemann}

Division of Endocrinology and Metabolism, Department of Intemal Medicine and Department of Clinical Chemistry, County Hospital, Aarhus, and Institute of Physiology, University of Aarhus, Denmark

Summary. Optimal experimental conditions were defined for measuring the initial uptake rate of the non-metabolizable sugar analogue 3-O-methylglucose in non-stimulated and insulin-stimulated human adipocytes. The permeability of the adipocyte plasma membrane for tracer methylglucose $(100 \mu \mathrm{mol} / \mathrm{l})$ was $2.9 \times 10^{-7} \mathrm{~cm} \times \mathrm{s}^{-1}$ at $37^{\circ} \mathrm{C}$ and slightly lower at $20^{\circ} \mathrm{C}$. At $37^{\circ} \mathrm{C}$ and $\mathrm{pH} 7.4$ insulin $(5 \mathrm{nmol} / \mathrm{l})$ increased the permeability about twofold (range 1.5 to fivefold) with half maximal effect at about $100 \mathrm{pmol} / \mathrm{l}$. At $\mathrm{pH} 7.0$ the dose response curve for the insulin effect on the uptake rate of methylglucose was shifted about 2.5 -fold to the right. The permeability to L-glucose due to simple diffusion was estimated as $3.0 \times 10^{-10} \mathrm{~cm} \times \mathrm{s}^{-1}$ suggesting that uptake of methylglucose occurs almost exclusively by facilitated diffusion. The $\mathrm{K}_{\mathrm{m}}$ for methylglucose equilibrium exchange in insulin stimulated cells was about $4.8 \mathrm{mmol} / \mathrm{l}$. The initial uptake of tracer methylglucose in insulin-stimulated cells was inhibited by unlabelled methylglucose and by $\mathrm{D}$-glucose with inhibition constants of about 3.8 and $7.7 \mathrm{mmol} /$ 1, respectively. Uptake of tracer 2-deoxyglucose (50 $\mu \mathrm{mol} / \mathrm{l})$ in insulin-stimulated adipocytes was linear from $10 \mathrm{~s}$ to $5 \mathrm{~min}$ whereas the rate of uptakc in the presence of $3 \mathrm{mmol} / \mathrm{l}$ of $\mathrm{D}$-glucose was markedly decreased suggesting that deoxyglucose uptake after a few minutes is mainly limited by hexokinase in the presence of glucose.

Key words: Methylglucose, glucose, deoxyglucose, insulin, collagenase, agitation

In a preceding paper we have shown that insulin binding to human adipocytes is readily measured at $37^{\circ} \mathrm{C}$ and that a steady state can be maintained for at least $2 \mathrm{~h}$ [1]. This is an important prerequisite for the study of the relation between insulin binding to adipocytes and its action at physiological temperature. The stimulation of hexose transport is an important and early effect of insulin which has been studied in some detail in rat adipocytes [2]. In the present paper we describe some characteristics of the hexose transport system in human adipocytes both in the absence of insulin and under conditions of steadystate insulin binding.

\section{Materials and Methods}

Chemicals, composition of buffer, preparation of adipocytes, and measurement of cell size are described in the preceding paper [1]. Additional chemicals were $3-\mathrm{O}-\left[{ }^{14} \mathrm{C} /\right.$ methyl-D-glucose $(59 \mathrm{mCi} /$ $\mathrm{mmol})$, and 2-deoxy-D-1-[14 $\mathrm{C}]$-glucose $(60 \mathrm{mCi} / \mathrm{mmol})$, both obtained from the Radiochemical Centre, Amersham, LK. Phloretin was from ICN Pharmaceuticals, Plainview, New York, USA.

\section{Subjects}

Specimens of subcutaneous adipose tissue were obtained from the abdomen of 40 females and 19 males undergoing gynaecological or gastroenterological surgery (sterilisation or duodenal ulcer). The paticnts were from 18 to 65 ycars old and their relative body wcight was $: 15 \%$ of ideal weight [3]. None of the donors suffered from endocrine disorders. The subjects werc fasted for about $12 \mathrm{~h}$ overnight. Preoperative medication was diazepam and atropine. General anaesthesia was induced with a short-acting barbiturate and maintained with halothane, nitrous oxide and oxygen.

\section{Hexose Transport-Studies}

Uptake of different hexuses was measured using a modification of the method described by Whitesell and Gliemann [2]. After the last two rinses of cells in glucose-free buffer $(10 \mathrm{mmol} / \mathrm{l}$ Hepes $\mid 1]$, $50 \mathrm{mg} / \mathrm{ml}$ human albumin, $\mathrm{pH} 7.4$ ) the cell suspension was concentrated to a volume fraction of adipocytes at 0.40 and $40 \mu \mathrm{l}$ aliquots were carefully placed in round-bottom polypropylene tubes $(11 \times$ 
Table 1. Factors influencing the response to insulin

\begin{tabular}{|c|c|c|c|}
\hline \multirow[t]{2}{*}{$\begin{array}{l}\text { Experimental } \\
\text { conditions: }\end{array}$} & \multicolumn{3}{|c|}{$\begin{array}{l}\text { Uptake rate of }\left[{ }^{14} \mathrm{C}\right]-\text { methylglucose at } 37^{\circ} \mathrm{C} \\
\text { during the initial } 5 \mathrm{~s} \text { in insulin-stimulated } \\
(5 \mathrm{nmol} / \mathrm{l}) \text { and noninsulin-stimulated (basal) } \\
\text { fat cells. Uptake rates are expressed in frac- } \\
\text { tions of equilibrium space for methylglu- } \\
\text { cose. }\end{array}$} \\
\hline & Basal & Insulin & $\begin{array}{l}\text { (Insulin- } \\
\frac{\text { Basal) } \times 100}{\text { Basal }}\end{array}$ \\
\hline \multicolumn{4}{|c|}{$\begin{array}{l}\text { a Effect of colla- } \\
\text { genase concentration } \\
\text { in buffer. }\end{array}$} \\
\hline $0.5 \mathrm{mg} / \mathrm{ml}$ & $0.10 \pm 0.04$ & $0.21 \pm 0.05$ & 1107 \\
\hline $1.0 \mathrm{mg} / \mathrm{ml}$ & $0.14 \pm 0.06$ & $0.26 \pm 0.07$ & 86 \\
\hline $2.0 \mathrm{mg} / \mathrm{ml}$ & $0.17 \pm 0.06$ & $0.26 \pm 0.05$ & 53 \\
\hline $3.0 \mathrm{mg} / \mathrm{ml}$ & $0.18 \pm 0.06$ & $0.26 \pm 0.06$ & 44 \\
\hline \multicolumn{4}{|l|}{$\begin{array}{l}\text { b Effect of mechani- } \\
\text { cal agitation }\end{array}$} \\
\hline Control & $0.11 \pm 0.04$ & $0.19 \pm 0.05$ & $73 \longrightarrow$ \\
\hline Agitation & $0.17 \pm 0.05$ & $0.18 \pm 0.04$ & $6 \ldots ـ p<0.05$ \\
\hline \multirow{2}{*}{$\begin{array}{l}\text { c Effect of prepara- } \\
\text { tion in glucose en- } \\
\text { riched media } \\
\text { Effect of prepara- } \\
\text { tion in glucose } \\
\text { free media }\end{array}$} & $0.10 \pm 0.03$ & $0.25 \pm 0.06$ & 1507 \\
\hline & $0.11 \pm 0.03$ & $0.21 \pm 0.06$ & $91-$ \\
\hline
\end{tabular}

Panel a: Adipocytes were prepared with different concentrations of collagenase.

Panel $b$ : Adipocytes were isolated with $0.5 \mathrm{mg} / \mathrm{ml}$ collagenase and prepared as described in Methods. Just before measurement of transport activity adipocyte suspensions were shaken ( 250 cycles/ $\mathrm{min}$ ) for $5 \mathrm{~min}$ (agitation).

Panel c: Adipocytes were isolated with $0.5 \mathrm{mg} / \mathrm{ml}$ collagenase and prepared in the presence or absence of $5 \mathrm{mmol} / 1$ glucose. Hexose transport was measured after two rinses in glucose free buffer.

All data are mean values of five individual experiments \pm 1 SD. Statistical analysis was done on the log transformed data

$50 \mathrm{~mm}$ ) in triplicate. Cells were then incubated without shaking for $45 \mathrm{~min}$ at $37^{\circ} \mathrm{C}$ before beginning of experiments. At the indicated times, $12 \mu \mathrm{l}$ of labelled hexose $(0.2 \mu \mathrm{Ci}$ methylglucose/tube or $0.1 \mu \mathrm{Ci}$ deoxyglucose/tube or $0.2 \mu \mathrm{Ci} \mathrm{L}$-glucose/tube) were injected directly into the cell mass with an automatic pipette. The incubation was terminated by the addition of $3 \mathrm{ml}$ of $154 \mathrm{mmol} / \mathrm{l}$ saline containing $0.3 \mathrm{mmol} / 1$ of phloretin and $0.15 \% \mathrm{v} / \mathrm{v}$ of ethanol. Silicone oil $(800 \mu \mathrm{l}$, relative density 0.99 , viscosity 100 centistokes) was layered on the top and the tubes were centrifuged within $3 \mathrm{~min}$ for $1 \mathrm{~min}$ at $2500 \times \mathrm{g}$. The $16 \mu \mathrm{l}$ of packed cells on the top of the oil layer was sucked into a plastic disposable pipette tip which was cut off and put into a counting vial with $5 \mathrm{ml}$ scintillation fluid. No variations of quenching were observed. Extracellular trapped radioactivity was measured by adding $1 \mathrm{ml}$ of phloretin solution to cells before injection of isotope. The uptake rates of hexoses were expressed as fractions of the equilibrium value for uptake of the nonmetabolizable sugar analogue methylglucose which was routinely measured after incubation for $30 \mathrm{~min}$. All values were corrected for extracellular trapped radioactivity which for methylglucose averaged $0.036 \pm 0.010(n=25$ consecutive experiments) of the equilibrium space for methylglucose. Methylglucose equilibrium space corrected for extracellularly trapped radioactivity was on several occasions found to be indistinguishable from the intracellular water space $\left({ }^{3} \mathrm{H}_{2} \mathrm{O}\right.$ space minus $\mathrm{L}-\left[{ }^{14} \mathrm{C}\right]-$ glucose space, data not shown).

\section{Analysis of Data for Hexose Transport}

$\left[{ }^{14} \mathrm{C}\right]$-methylglucose clearance (i. e. the volume of extracellular medium from which methylglucose is removed completely per unit time by influx into initially sugar free cell water) was determined as counts per minute $(\mathrm{cpm})$ taken up per cell per second/cpm per $\mathrm{cm}^{3}$ medium. The permeability of the adipocyte plasma membrane for tracer methylglucose was calculated as

$$
\frac{\text { clearance }\left(\mathrm{cm}^{3} \times \mathrm{s}^{-1}\right)}{\text { mean cell surface area }\left(\mathrm{cm}^{2}\right)}
$$

$K_{m}$ for methylglucose equilibrium exchange (transport of labelled sugar under conditions with equal extracellular and intracellular concentration of unlabelled sugar) was defined as the concentration of methylglucose which gives half maximal exchange of methylglucose and calculated according to

$\mathrm{t}_{1 / 2 c}=\left(1+\frac{c}{\mathrm{~K}_{\mathrm{m}}}\right) \times \mathrm{t}_{1 / 2 \text { (tracer) }}$

Where $c$ is the concentration of unlabelled methylglucose in the aqueous phases and $t_{t / 2}$ the half time for uptake of labelled methylglucose alone (index tracer) or in the presence of methylglucose at concentration $c . K_{i}$ was defined as the concentration of unlabelled methylglucose or D-glucose which inhibits the uptake rate of tracer methylglucose $50 \%$ in initially sugar free cells.

\section{Precision of Transport Measurement}

In noninsulin-stimulated adipocytes the coefficient of variation was 1) 0.018 for extracellularly trapped radioactivity 2) 0.017 for methylglucose uptake at equilibrium 3) 0.073 for methylglucose uptake rate during the first $5 \mathrm{~s}(n=25$ consecutive experiments). Thus, the total coefficient of variation for measurement of tracer methylglucose uptake rate during $5 \mathrm{~s}$ (expressed in fraction of intracellular cell water) was 0.096 in absence of insulin, and slightly lower in its presence.

\section{Evaluation of Experimental Conditions}

Unfortunately purified collagenase is unable to liberate adipocytes from fat tissue [4]. The batches of commercial crude collagenase contain variable types and amounts of enzymes with trypsin-like activities [5]. Accordingly, the metabolic activity of isolated cells may depend on the batch and concentration of collagenase used for cell liberation. This study showed a collagenase concentrationdependent increase of basal influx rate of methylglucose (Table 1a). Moreover, we found a twofold shift to the right of the doseresponse curve for the insulin effect on the uptake rate of methylglucose when adipocytes isolated with $0.5 \mathrm{mg} / \mathrm{ml}$ collagenase were compared with adipocytes isolated with $3.0 \mathrm{mg} / \mathrm{ml}$ collagenase (data not shown). Hence, the use of one batch and a constant and low concentration of collagenase is mandatory in comparative studies on isolated adipocytes. Mechanical agitation had an insulin-like effect on hexose transport (Table 1b). Shaking and centrifugation during the preparation procedure should therefore be limited and standardized $[6,7]$. Preparation of fat cells in glucose free media caused a reduction of the insulin effect on methylglucose uptake (Table 1c), probably due to energy depletion [7]. The concentration of albumin in final incubation buffer had no consistent influence on hexose transport activity (data not shown). However, as elaborated in the preceding paper [1] a high concen- 
Fraction of equilibrium space for methylglucose

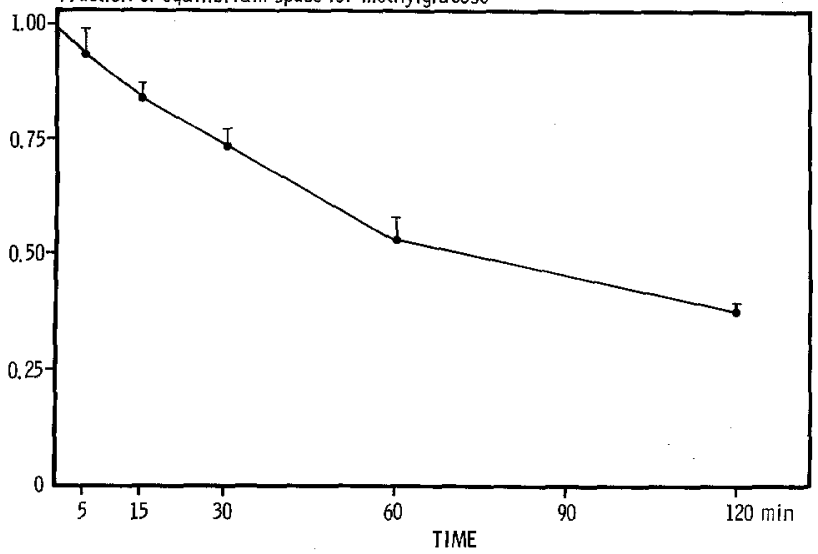

Fig. 1. Effect of phloretin on efflux of $\left[{ }^{14} \mathrm{C}\right]$ methylglucose. Maximally insulin-stimulated $(5 \mathrm{nmol} / \mathrm{l})$ adipocytes were incubated with $\left[{ }^{14} \mathrm{C}\right]$ methylglucose $(100 \mu \mathrm{mol} / 1)$ for $30 \mathrm{~min}$ at $37^{\circ} \mathrm{C}$. At time zero, $3 \mathrm{ml}$ of saline containing $0.3 \mathrm{mmol} / 1$ of phloretin was added and the tubes were centrifuged at the times indicated. Mean values of three individual experiments \pm 1 SEM

tration of albumin in fat cell buffer is needed to minimize cell traumatization. Bovine serum albumin (fraction V) may contain variable amounts of substances with insulin-like activities [8]. Consequently, highly purified human albumin should be used in studies of human adipocytes.

It is essential that the phloretin stopping solution works efficiently and almost immediately to prevent efflux of cell accumulated hexose. Figure 1 shows that the loss of methylglucose from the intracellular pool of phloretin treated cells was $1.2 \% / \mathrm{min}$. Thus, the stopping procedure was adequate since adipocytes were centrifuged within $3 \mathrm{~min}$ of stopping the reaction between hexose and cells. The permeability of the phloretin treated cells with respect to tracer methylglucose was about $0.6 \%$ of the uninhibited permeability (Fig. 2).

A significant negative correlation was found between fat cell volume and the intracellular water space per volume packed cells ( $r=-0.74, p<0.001, n=50$ consecutive experiments). Thus, the difference between the space at time zero and that any given time will decrease with increasing cell size.

\section{Statistical Methods}

In text and table results are presented as mean $\pm 1 \mathrm{SD}$. In the Figures data are given as mean \pm 1 SEM. Student's t-test was used to test the significance of paired observations. Linear regression analysis was employed in a correlation study using the leastsquares method. The number of samples ( $n$ ) equals the number of persons.

\section{Results}

Figure 2 depicts the time course for uptake of methylglucose $(100 \mu \mathrm{mol} / 1)$ and the effect of insulin. It is seen that the initial velocity can be measured between 5 and $10 \mathrm{~s}$. The permeability at $37^{\circ} \mathrm{C}$ was calculated from Fig. 2 as $2.5 \times 10^{-7} \mathrm{~cm} \times \mathrm{s}^{-1}$ in the absence of insulin and $5.0 \times 10^{-7} \mathrm{~cm} \times \mathrm{s}^{-1}$ in its

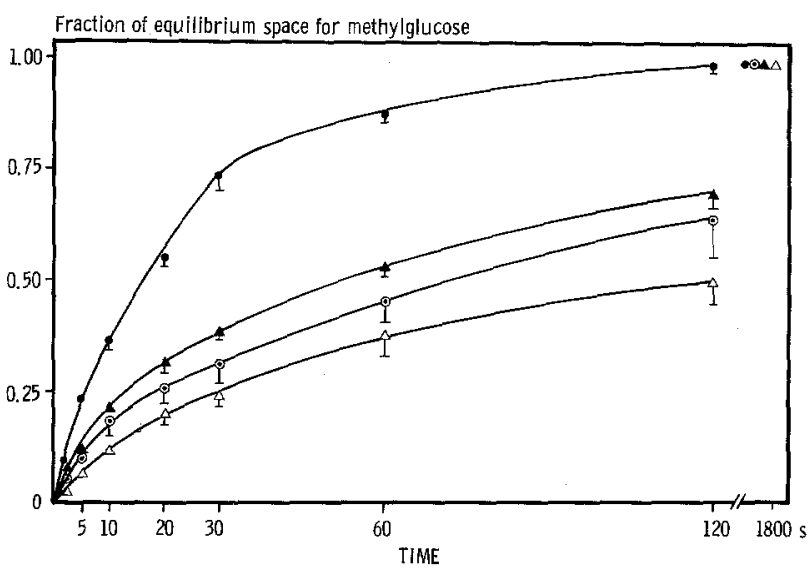

Fig. 2. Time course for uptake of $100 \mu \mathrm{mol} / 1\left[{ }^{14} \mathrm{C}\right]$ methylglucose. Triangles indicate uptake at $20^{\circ} \mathrm{C}$ and circles indicate uptake at $37^{\circ} \mathrm{C}$. Closed symbols: maximally insulin-stimulated $(5 \mathrm{nmol} / \mathrm{l})$ cells and open symbols: basal cells. Cell diameter averaged $76 \pm$ $3 \mu \mathrm{m}$. Mean values of six individual experiments \pm 1 SEM

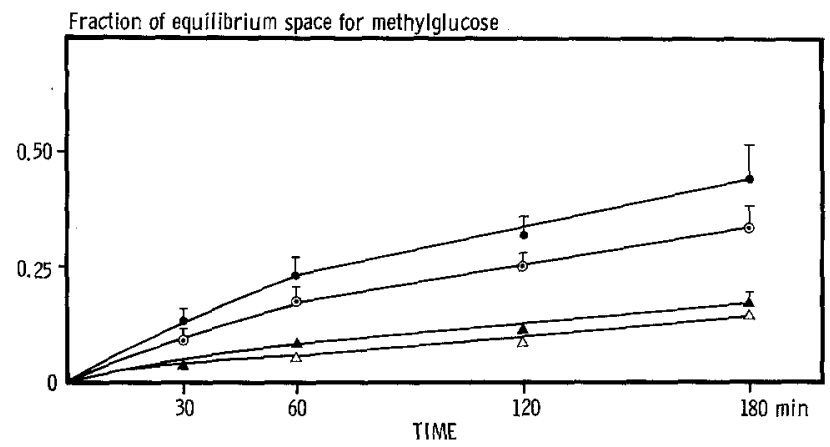

Fig. 3. Uptake rate of $100 \mu \mathrm{mol} / \mathrm{l}$ of $\left[{ }^{14} \mathrm{C}\right]-\mathrm{L}$-glucose. Uptake rate was measured at $37^{\circ} \mathrm{C}$ in the absence (circles) and in the presence (triangles) of $40 \mathrm{mmol} / 1$ of unlabelled methylglucose. Closed symbols: maximally insulin-stimulated $(5 \mathrm{nmol} / \mathrm{l})$ cells. Open symbols: basal transport. Mean values of three individual experiments \pm 1 SEM

presence $(5 \mathrm{nmol} / \mathrm{l})$. Calculated from the combined data of 30 separate experiments the permeability was

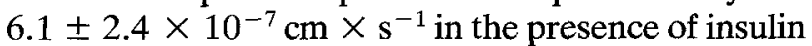
$(5 \mathrm{nmol} / 1)$ and $2.9 \pm 0.4 \times 10^{-7} \mathrm{~cm} \times \mathrm{s}^{-1}$ in its absence. An increase in temperature from $20^{\circ} \mathrm{C}$ to $37^{\circ} \mathrm{C}$ nearly doubled the maximal permeability for tracer methylglucose. The insulin effect was slightly greater at $37^{\circ} \mathrm{C}$ than at room temperature (Fig. 2).

The rate of L-glucose uptake $(100 \mu \mathrm{mol} / 1)$ is shown in Fig. 3. L-glucose was taken up at a much slower rate than D-methylglucose. Insulin stimulated the uptake indicating that carrier-facilitated transport was involved. Moreover, $40 \mathrm{mmol} / 1$ of unlabelled methylglucose inhibited L-glucose uptake markedly. The permeability of L-glucose in the presence 


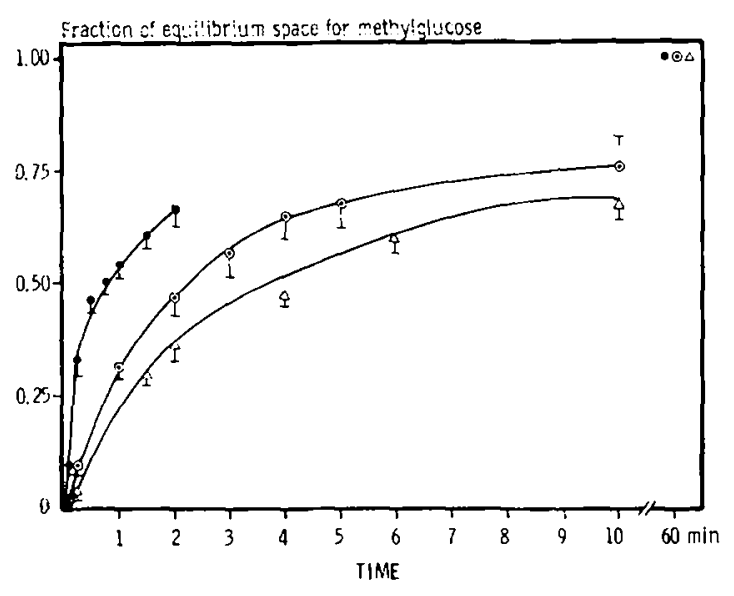

Fig. 4. Equilibrium exchange of methylglucose. Uptake rate was measured at $37^{\circ} \mathrm{C}$ in maximally insulin-stimulated $(5 \mathrm{nmol} / 1)$ cells. Uptake of $100 \mu \mathrm{mol} / 1\left[{ }^{14} \mathrm{C}\right]$ methylglucose $(-)$ ) and uptake of $10 \mathrm{mmol} / \mathrm{l}(\odot-\odot)$ or $20 \mathrm{mmol} / 1(\Delta-\Delta)$ methylglucose in cells equilibrated for $1 \mathrm{~h}$ with 10 or $20 \mathrm{mmol} / \mathrm{h}$ unlabelled methylghucose. The mean half-times for uptake were $45 \mathrm{~s}$ for tracer, $140 \mathrm{~s}$ for $10 \mathrm{mmol} / 1$ methylglucose and $240 \mathrm{~s}$ for $20 \mathrm{mmol} / 1$ methylglucose. Mean values of six individual experiments \pm 1 SEM

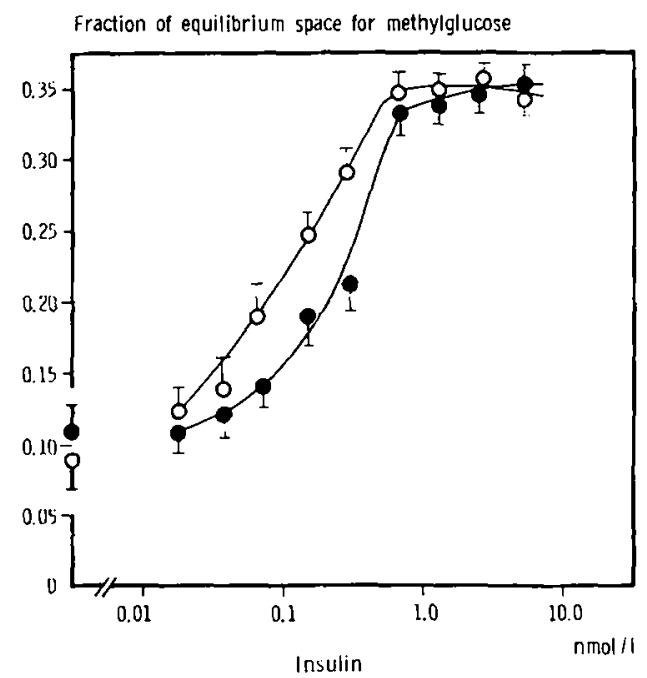

Fig. 6. Stcady-state insulin dose-response rclationship. Uptake rate of $100 \mu \mathrm{mol} / 1\left[{ }^{14} \mathrm{C}\right]$ methylglucose was measured at $37^{\circ} \mathrm{C}$ in cells, preincubated at $37^{\circ} \mathrm{C}$ for $1 \mathrm{~h}$ in buffers at $\mathrm{pH} 7.4(\mathrm{O}-\mathrm{O})$ or at 7.0 (-) and with insulin in the concentrations indicated on the abscissa. Uptake rate was measured during the initial $5 \mathrm{~s}$. Degradation of labelled insulin in the cell suspension by the time transport was measured, was $2 \%$ as cstimated by solubility in $12 \% \mathrm{w} / \mathrm{v}$ trichloroacetic acid. Mean values of three individual experiments \pm 1 SFM

of unlabelled methylglucose, which may be considered an estimate of simple diffusion, was $3.0 \times 10^{-10}$ $\mathrm{cm} \times \mathrm{s}^{-1}$ or about 1,000 times lower than the permeability of methylglucose in the absence of insulin. The permeability to methylglucose in the presence of

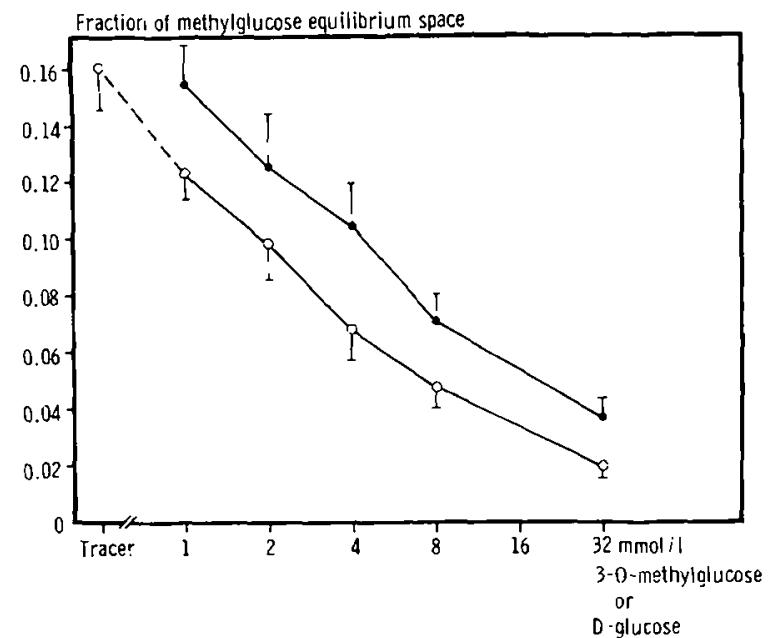

Fig. 5. Inhibition of $\left[{ }^{14} \mathrm{C}\right]$ methylglucose uptake rate by methylglucose and glucose. Twelve $\mu \mathrm{l}$ buffer containing $\left[{ }^{14} \mathrm{C}\right]$ methylglucose $(100 \mu \mathrm{mol} / \mathrm{l})$ and unlabelled methylglucose $(0-0)$ or unlabelled glucose (-) in concentrations thrce times those indicated on the abscissa werc added to $40 \mu \mathrm{l} 40 \% \mathrm{v} / \mathrm{v}$ (with $24 \mu \mathrm{l}$ of aqueous phase) of maximally insulin-stimulated $(5 \mathrm{nmol} / \mathrm{l})$ cells. Uptake rate was measured during the initial $5 \mathrm{~s}$. Mean values of five individual experiments \pm 1 SEM

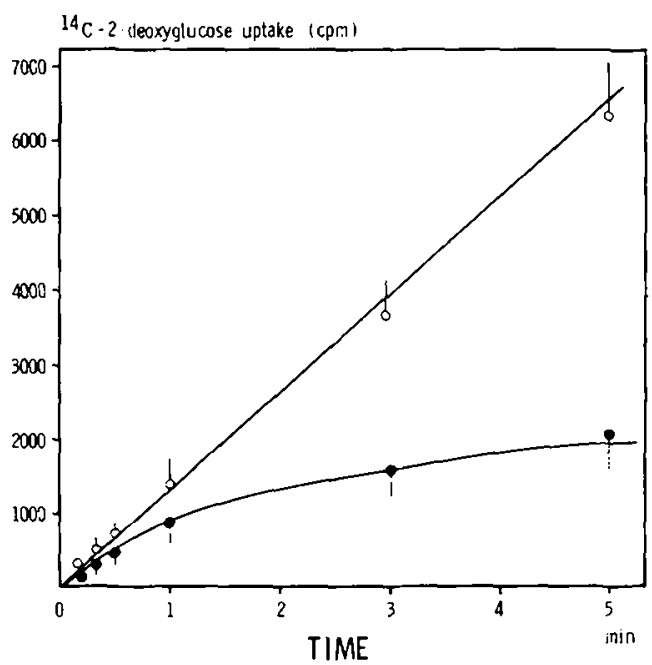

Fig. 7. Uptake of deoxyglucose. Uptake of $50 \mu \mathrm{mol} / 1\left[{ }^{14} \mathrm{C}\right]$-deoxyglucose was measured at $37^{\circ} \mathrm{C}$ in maximally insulin-stimulated $(5 \mathrm{umol} / \mathrm{l})$ cells in the absence $(\mathrm{O}-\mathrm{O})$ and in the presence of $3.3 \mathrm{mmol} / 1$ of unlabelled glucose $(-)$ in the final incubation volume. $\left[{ }^{14} \mathrm{Cl}\right]$-deoxyglucose and glucosc were added to the cells at the same time. Data are expressed as cpm per sample. Mean values of three individual experiments $=1 \mathrm{SEM}$

$80 u \mathrm{~mol} / \mathrm{l}$ cytochalasin B was $5.0 \times 10^{-9} \mathrm{~cm} \times \mathrm{s}^{-1}$ (data not shown).

Figure 4 shows experiments in which equilibrium exchange rate of methylglucose in insulin stimulated adipocytes was measured both with tracer methylglu- 
cose $(100 \mu \mathrm{mol} / \mathrm{l})$ alone and with 10 or $20 \mathrm{mmol} / \mathrm{l}$ unlabelled methylglucose. $K_{m}$ (equilibrium exchange) was calculated as $4.7 \pm 1.3 \mathrm{mmol} / \mathrm{l}$ from the results with $10 \mathrm{mmol} / \mathrm{l}$ and as $4.9 \pm 0.6 \mathrm{mmol} / \mathrm{l}$ from those with $20 \mathrm{mmol} / \mathrm{l}$ methylglucose.

The inhibition constant $\left(\mathrm{K}_{\mathrm{i}}\right)$ of methylglucose on the net uptake (intracellular sugar concentration is initially zero) of tracer methylglucose (Fig. 5) was of the same magnitude $(3.8 \pm 1.1 \mathrm{mmol} / \mathrm{l})$ as $\mathrm{K}_{\mathrm{m}}$ for equilibrium exchange. $K_{\mathrm{i}}$ for net uptake of D-glucose (Fig. 5) was about twice as high as for methylglucose $(7.7 \pm 1.9 \mathrm{mmol} / \mathrm{l})$.

The steady-state insulin dose-response relationship on methylglucose transport at $37^{\circ} \mathrm{C}$ is depicted in Fig. 6. At pH 7.4 insulin caused a 2.5 -fold increase above basal level in initial uptake rate with a maximal effect at an insulin concentration of about $1 \mathrm{nmol} / \mathrm{l}$. Half-maximal stimulation was observed at an insulin concentration of about $0.100 \mathrm{nmol} / \mathrm{l}$. A change of buffer $\mathrm{pH}$ from 7.4 to 7.0 caused a 2.5 -fold shift of the dose response curve to the right (Fig. 6). In contrast basal and maximally insulin stimulated methylglucose uptake rate was independent of buffer $\mathrm{pH}$ in the range 7.0 to 7.6 . At $\mathrm{pH}$ above 7.6 a decline in insulin enhanced influx occurred (data not shown).

Figure 7 shows the uptake of tracer deoxyglucose $(50 \mu \mathrm{mol} / \mathrm{l})$ with time at $37^{\circ} \mathrm{C}$ in maximally insulin stimulated adipocytes in the absence and presence of $3.3 \mathrm{mmol} / 1$ of $\mathrm{D}$-glucose. The uptake of tracer alone appeared linear from $10 \mathrm{~s}$ to $5 \mathrm{~min}$ whereas the uptake in the presence of $\mathrm{D}$-glucose was progressively non-linear.

\section{Discussion}

The half times of uptake of tracer methylglucose in this study were similar to those reported by Ciaraldi et al. [9]. The permeability of the human adipocyte plasma membrane to tracer methylglucose in the absence of insulin $\left(2.9 \times 10^{-7} \mathrm{~cm}^{\circ} \times \mathrm{s}^{-1}\right)$ was about half of that of the rat adipocyte membrane $\left(6 \times 10^{-7}\right.$ $\left.\mathrm{cm} \times \mathrm{s}^{-1}\right)$ [2]. If it is assumed that the turnover is the same on the human and rat carrier, this indicates that the number of functional carriers per unit surface area is roughly half in the human adipocytc as compared to the rat adipocyte. In the presence of insulin the permeability of the human adipocyte $\left(6.1 \times 10^{-7}\right.$ $\left.\mathrm{cm} \times \mathrm{s}^{-1}\right)$ was much lower than that of small rat adipocytes $\left(60 \times 10^{-7} \mathrm{~cm} \times \mathrm{s}^{-1}\right)$ [2]. The effect of insulin may to a large extent be due to recruitment of hexose transport sites from an intracellular pool to the plasma membrane $[10,11]$. Therefore, the combined data suggest that the adipocyte of adult man is able to recruit only a limited number of additional transport sites as a result of binding of insulin to its receptor.

L-glucose was transported very slowly across the cell membrane and partially via the carrier-facilitated and insulin responsive mechanism. Similar findings have been described in rat adipocytes [2]. The permeability of L-glucose accounted for by simple diffusion (i. e. in the presence of a near-saturating concentration of methylglucose) as well as the permeability for methylglucose in the presence of phloretin and cytochalasin $\mathrm{B}$ was less than $2 \%$ of the carrierfacilitated permeability of tracer methylglucose. Consequently, kinetic data for the rapidly transported sugars, methylglucose and glucose, were not corrected for simple diffusion.

The $\mathrm{K}_{\mathrm{m}}$ for equilibrium exchange of methylglucose was about $4.8 \mathrm{mmol} / \mathrm{l}$ which is nearly the same as in rat adipocytes $[2,12]$. Equilibrium exchange can only be measured for nonmetabolizable sugar analogues and, in order to estimate $\mathrm{K}_{\mathrm{m}}$ for transport of $\mathrm{D}$-glucose, net uptake was measured. The initial influx rates tend to be underestimated at high sugar concentrations due to the nonexponential nature of the net flux curve [2]. Thus, $K_{m}$ for net influx is slightly underestimated and it is likely that the true $\mathrm{K}_{\mathrm{m}}$ for net influx of methylglucose (measured value $3.8 \mathrm{mmol} / \mathrm{l}$ ) is not different from $\mathrm{K}_{\mathrm{m}}$ for equilibrium exchange $(4.8 \mathrm{mmol} / \mathrm{l})$. This shows that the transport system is not asymmetrical in the same way as that of human erythrocytes in which $\mathrm{K}_{\mathrm{m}}$ for equilibrium exchange is more than 10 times higher than that for net influx [13]. The measured $\mathrm{K}_{\mathrm{m}}$ for net glucose uptake $(7.7 \mathrm{mmol} / \mathrm{l})$ was twice as high as that for methylglucose, which is in agreement with the results of Ciaraldi et al. [9] and Whitesell and Gliemann [2].

The almost identical behaviour of three sugars in human and rat adipocytes suggests that their transport systems are very similar. In this context it should be pointed out that a transport $\mathrm{K}_{\mathrm{m}}$ of $1.9 \mathrm{mmol} / \mathrm{l}$ has been reported previously for $\mathrm{D}$-glucose in rat adipocytes [14]. This apparent $K_{m}$ was estimated as the inhibition constant of glucose on the uptake after 3 min of tracer deoxyglucose, a sugar which is phosphorylated by hexokinase but not further metabolized. However, it has been shown in rat adipocytes that glucose not only inhibits transport but also occupies the hexokinase as time progresses and glucose accumulates in the intracellular water [15]. Therefore, tracer deoxyglucose accumulates in the intracellular water due to its diminished rate of phosphorylation and the net uptake rate decreases [15]. The present data on deoxyglucose in combination with glucose $(3.3 \mathrm{mmol} / \mathrm{l})$ strongly suggest that the same events occur in human adipocytes. Hence, methylglucose should be used as a probe for meas- 
uring hexose transport activity in future clinical studies.

\section{Relationships Between Insulin Receptor Binding and Hexose Transport}

About $1 \mathrm{nmol} / \mathrm{l}$ insulin is required to obtain maximal stimulation of hexose transport (Fig. 6). Thus, about $25 \%$ of the insulin receptors are needed to obtain a maximal biological effect of insulin (cf. Fig. 4 of [1]). In adipocytes from young rats a maximal insulin effect is obtained with an occupancy of about $4 \%$ [16]. Hence, the phenomenon of "spare" receptors appears less marked in adipocytes from adult man than in those from growing rats.

Insulin binding is considerably lower at $\mathrm{pH} 7.0$ when compared to $\mathrm{pH} 7.4$ [1]. The functional consequence of a decrease of insulin binding is an impaired insulin sensitivity. Accordingly, a change of buffer $\mathrm{pH}$ from 7.4 to 7.0 caused a rightward shift of the dose response curve for the insulin effect on hexose transport.

Acknowledgements. For supply of fat biopsics we are indebted to the staff of the Departments of Surgery, Aarhus Amtssygehus and Aarhus Kommunehospital, and the Department of Obstetrics and Gynaecology, Aarhus Kommunehospital. T. Skrumsager, L. Busch, J. Jørgensen and I.. Blak are thanked for skillful technical assistance. The study was supported by grants from Danish Medical Research Council, Landsforeningen for Sukkersyges Fond, Aarhus Universitets Forskningsfond, Novo Fond and Nordisk Insulin Fond.

\section{References}

1. Pedersen $\mathrm{O}$, Hjøllund $\mathrm{E}$, Beck-Nielsen $\mathrm{H}$, Lindskov $\mathrm{HO}$, Sonne O, Gliemann J (1981) Insulin receptor binding and receptor mediated insulin degradation in human adipocytes. Diabetologia 20: 636-641

2. Whitesell RR, Gliemann J (1979) Kinetic parameters of transport of 3-0-methylglucose and glucose in adipocytes. J Biol Chem 254: 5276-5283

3. Geigy Scientific Tables (1970) 7th edn
4. Kono $T$ (1969) Roles of collagenases and other proteolytic enzymes in the dispersal on animal tissues. Biochim Biophys Acta 178: $397-400$

5. Fain JN (1975) Isolation of free brown and white fat cells. Methods Enzymol 35: 555-561

6. Gliemann J (1967) Assay of insulin-like activity by the isolated fat cell method. I. Factors influencing the response to crystalline insulin. Diabetologia 3: 382-388

7. Vega FV, Kono T (1979) Sugar transport in fat cells: Effects of mechanical agitation, cell-bound insulin and temperature. Arch Biochem Biophys 192: 120-127

8. Lawrence JC Jr. Guinovart JJ, Larner J (1977) Activation of rat adipocyte glycogen synthase by insulin. J Biol Chem 252: $444-450$

9. Ciaraidi TP, Koltcrman OG, Sicgel JA, Olefsky JM (1979) Insulin-stimulated glucose transport in human adipocytes. Am J Physiol 236: 621-625

10. Cushman SW, Wardzala LJ (1980) Potential mechanism of insulin action on glucose transport in the isolated rat adipose cell. J Biol Chem 255: 4758-4762

11. Suzuki K, Kono T (1980) Evidence that insulin causes translocation of glucose transport activity to the plasma membrane from an intracellular storage site. Proc Natl Acad Sci USA 77: $2542-2545$

12. Vinten J, Gliemann J, Ósterlind LK (1976) Exchange of 3-0methylglucose in isolated fat cells. Concentration dependence and effect of insulin. J Biol Chem 251: 794-800

13. Regen MD, Tarpley HL (1974) Anomalous transport kinetics and the glucose earrier hypotheses. Biochim Biophys Acta 339: $218-233$

14. Olefsky JM (1978) Mechanisms of the ability of insulin to activate the glucose transport system in rat adipocytes. Biochem J 172: 137-145

15. Folcy JE, Foley R, Glicmann J (1980) Rate limiting steps of 2-deoxyglucose uptake in rat adipocytes. Biochim Biophys Acta 599: 689-698

16. Gammeltoft S, Gliemann J (1973) Binding and degradation of ${ }^{125}$ I-labelled insulin by isolated rat fat cells. Biochim Biophys Acta 320: $16-32$

Received: 15 September 1980

and in revised form: 13 October 1980

Dr. Oluf Pedersen

Medical Department III

County Hospital

Tage Hansensgade

DK-8000 Aarhus C

Denmark 